\title{
MARCAS DA VIOLÊNCIA NO CONTO "STRESS", DE LÍLIA MOMPLÉ
}

\author{
FEATURES OF VIOLENCE IN "STRESS" BY \\ LILIA MOMPLÉ
}

Franciane Conceição da Silva ${ }^{1}$

\section{RESUMO}

No presente artigo, fazemos um estudo do conto "Stress", extraído da obra Os olhos da cobra verde (1997), de Lília Momplé, escritora moçambicana. Nesta narrativa, Momplé encena a história de personagens que, em consequência da guerra civil de Moçambique, vão se transformando, sendo representados, ao mesmo tempo, como vítimas e algozes. A análise das estratégias narrativas utilizadas por Momplé para encenar a violência que desfigura os personagens constitui o foco de nossa investigação.

PALAVRAS-CHAVE: Lília Momplé; Encenação da Violência; Literatura Moçambicana.

\section{ABSTRACT}

In this paper I examine the remarks around "Stress", a tale retrieved from the book Os olhos da cobra verde (1997), by Lília Momplé, a Mozambican writer. In this narrative, Momple presents the story of characters who, as a consequence of the civil war in Mozambique, are changing, being represented, at the same time, as victims and tormentors. The analysis of the narrative strategies used by Momplé to represent a violence that strip the characters constitutes the focus of our investigation.

KEYWORDS: Lília Momplé; Representation of Violence; Mozambican Literature. 
"Stress" é o primeiro conto da coletânea Os olhos da cobra verde (1997), terceiro livro da escritora moçambicana Lília Momplé. Anteriormente, a autora havia publicado as obras Ninguém matou Suhura, antologia de contos lançada em 1988, e o romance Neighbours (1995). "Stress" é um texto que nos apresenta uma multidão de rostos sem nomes. Os personagens do conto, vivendo num ambiente extremamente violento, são invadidos por uma profunda melancolia e tentam sobreviver em meio a um horizonte sem perspectivas. Esse aspecto das narrativas de Momplé é acentuado em consideração do pesquisador Anselmo Alós, quando observa:

Lília Momplé, através de seus contos, resgata os dilemas da nação moçambicana através das experiências de sujeitos subalternizados, dos cidadãos de segunda categoria, daqueles que dificilmente teriam suas histórias contadas, e isso redimensiona a compreensão que o leitor tem da realidade pós-colonial moçambicana. (Alós, 2013, p.401)

O conto "Stress" encena a história de uma personagem feminina não nomeada, descrita pelo narrador onisciente de acordo com a função que ocupa: "amante do major-general" (Momplé, 1997, p.9). A história desta se desenrola simultaneamente a de um professor que leva uma vida miserável, trabalhando incansavelmente para sustentar a família. As ações das personagens são assumidas por uma voz narrativa que tudo sabe, tudo vê, inclusive, adiantando episódios que acontecerão no futuro, despertando, com essa estratégia, a curiosidade do/da leitor/a. O mote da história e o desfecho inesperado da trama se dão em consequência da obsessão que a protagonista do conto, a amante do major-general, cria em relação ao professor, o seu vizinho. O homem, consumido pela dificuldade de equilibrar os muitos compromissos com a família ao precário salário que recebe no magistério, sequer conhece a vizinha. A mulher, extremamente vaidosa e certa do seu poder de sedução, não se conforma em não ser notada pelo vizinho, que insiste, na percepção dela, em resistir aos seus encantos. $\mathrm{O}$ trecho abaixo destacado exemplifica essa situação:

A amante do major-general crava os olhos no homem que está sentado na varanda do $2^{\circ}$ andar mesmo em frente e sibila, indignada: "bêbado". [...] O homem vai bebericando a cerveja com uma sofreguidão mal contida, a atenção centrada no copo e no Xirico2. Por um instante, por um brevíssimo instante, a amante do major-general supõe que ele dá pela sua presença, mas logo se apercebe que, como sempre, aquele olhar resvalante a exclui do seu campo de visão, inteiramente preenchido pelo Xirico e pelo copo de cerveja. (Momplé, 1997, p. 9)

$\mathrm{O}$ ato, que pode ser considerado uma espécie de ritual, repete-se todos os domingos, quando, depois de se maquiar e se vestir, a mulher vai para varanda que dá para a rua e observa fixamente o vizinho que nunca olha para ela. O ritual de embelezamento da personagem é descrito com minúcias pelo narrador do conto, que apresenta um discurso nada impar- 
cial. Ao contar a história, a voz narrativa de "Stress" opina e julga o comportamento das personagens. Esse aspecto do texto é comentado por Anselmo Peres Alós, quando observa que, em todos os seus contos, Lília Momplé

Adota um narrador em terceira pessoa e onisciente, e a focalização narrativa oscila entre a focalização interna (na qual a voz narrativa tem acesso aos pensamentos e ao universo interior das personagens) e a narrativa externa (na qual, a partir de um locus exterior ao universo diegético instaurado pelos eventos narrados, a voz narrativa emite seus juízos e comentários acerca dos eventos que vão sendo apresentados ao leitor) (Alós, 2011, p. 1005-1006)

Em determinado momento do conto, a voz narrativa faz o seguinte comentário sobre o ritual de beleza da amante do major-general: "Ela se entrega com o zelo das mulheres que vivem sós e procuram, com a sua aparência cuidada, compensar a solidão, provocando nos outros admiração, invejas e secretos desejos" (Momplé, 1997, p.10). A partir desse comentário, apreendemos que, ao mesmo tempo em que a voz narrativa condena o comportamento da amante do major-general, deixa escapar o fascínio que a personagem lhe exerce. $\mathrm{O}$ narrador também pode ser considerado um desses "outros" a quem a mulher provoca "admiração", "invejas" e "secretos desejos". Talvez numa tentativa de esquivar-se dos encantos que a exuberante figura feminina lhe causa, o narrador começa a ressaltar as muitas qualificações negativas da personagem. Desta forma, ao descrever o espaço habitado pela vizinha do professor, a voz narrativa assim se manifesta:

A sala é, na verdade, um lugar que suscita, nos visitantes de espírito mais sensível, uma melancolia insidiosa e funda que, por vezes, no meio de uma conversa, os leva a despedir-se, acossados de pressa, como se, de súbito, lhes falte o ar, naquele ambiente, onde o luxo, aliado a um notório mau gosto, produz um efeito de extrema opressão. E os próprios visitantes se espantam com a urgência que os move a demandar a rua, pois ignoram que a melancolia acumulada assim, inconscientemente, chega a ser mais insuportável que a própria dor. (Momplé, 1997, p.9)

A partir das explicações dadas pelo narrador, descobrimos que a amante do major-general vive em um imóvel que recebeu de presente do militar, situado num dos bairros mais tradicionais da cidade, "segregado por prédios e vivendas construídos, ainda no tempo colonial, por empreiteiros portugueses, com muito dinheiro e duvidoso gosto" (Momplé, 1997, p.11). A sala da residência é o espaço em que a amante do major-general se sente como uma rainha. O local é o seu reino particular e todos os objetos que o compõem foram escolhidos por ela. A ostentação do espaço que provoca tanto incômodo em alguns visitantes talvez se deva ao fato da riqueza do ambiente contrastar com a extrema pobreza que assola grande parte da população, sobretudo das comunidades rurais de Moçambique, que sofrem com os efeitos da sangrenta guerra civil ${ }^{3}$. O flat, símbolo de ascensão 
social da amante do major-general, é também representação do fracasso de "um casal de funcionários públicos que, estrangulado pelo constante aumento do custo de vida, resolveu regressar à sua suburbana Mafalala" (Momplé, 1997, p.12).

A sensação sufocante, que se apresenta nos primeiros parágrafos do conto, vai crescendo à medida que os acontecimentos se desencadeiam e a violência se instaura. As ações da amante do major-general, de certo modo, são movidas pela melancolia que a envolve, perpassando o ambiente em que ela vive. Esse aspecto da narrativa de Momplé também é apontado pelo pesquisador Anselmo Alós, que afirma:

No projeto ficcional de Lília Momplé, torna-se evidente um esforço de vencer a amnésia social, com vistas a manter vivas as recordações das violências e das arbitrariedades colonialistas. A beleza de seus contos é diametralmente proporcional à crueza da violência descrita ao longo das páginas [...]. É recorrente, em suas narrativas, a presença de uma melancolia histórica, provocada pelo apagamento das agruras da luta pela independência das ex-colônias africanas, e de um atento olhar para os desfavorecidos que mais sofreram durante a história moçambicana ao longo do século XX. (Alós, 2011, p. 1008)

A melancolia que atinge os personagens do conto, de algum modo, também alcança os leitores e leitoras. Tornamo-nos prisioneiras do espaço tedioso construído por Lília Momplé. Assim como a poeira que se agita querendo se libertar da sala luxuosa, mas melancólica, agitamo-nos para saber o que vai acontecer no desenvolvimento da história. Desta forma, num compasso lento e tedioso, vislumbramos a amante do major-general, embriagada pela "sensação que sempre lhe provoca o facto de constatar que tudo quanto os seus olhos abarcam lhe pertence" (Momplé, 1997, p.10 - grifo nosso).

Pertencer é um verbo que muito diz sobre a personagem e move muitas das ações praticadas por ela. De algum modo, a mulher se sente bem no ambiente que tanto incomoda aos seus visitantes, porque ela é apenas mais um elemento que compõe esse cenário. Ela é apenas mais um enfeite da sala luxuosa, onde até "mesmo a poeira parece circular agitadamente, ansiosa por se libertar de tamanha ostentação" (Momplé, 1997, p.9). A personagem, envaidecida pelo luxo que o major-general lhe proporciona, contenta-se em ser um ornamento que enfeita a vida do ex-militar, apenas aos domingos. Nos outros dias da semana, a amante solitária permanece presa ao seu castelo ilusório, acreditando ser uma rainha. De acordo com o professor John Rex, em estudo realizado sobre o conto "Stress":

Certamente, a cor das paredes, o tipo e a disposição da mobília, a adequação do espaço às necessidades do(s) ocupante(s) podem afetar o astral deste(s), mas a verdadeira fonte dessa solidão e acompanhante melancolia é a relação entre o homem (o major-general) e a mulher (a amante). Percebe- 
-se uma polarização homem-mulher, traduzida na enorme clivagem de interesses e atitudes entre os dois: contra o capricho, a elegância (no vestir, na maquiagem, nos cuidados do corpo e na etiqueta geral) e a sensualidade da amante, o descaso, a grosseria e a falta de prumo do major-general. (Rex, 2007, p.445)

A contradição apontada por Rex reforça o nosso ponto de vista de enxergar a mulher enquanto ornamento. A personagem é, de certo modo, um objeto de uso (pessoal e irrestrito) do major-general. Ela pertence ao amante, mas vive tão presa à realidade que criou para si, tão presa à sua própria vaidade, que não tem consciência do quanto é escrava de seus próprios desejos. Inebriada pela sensação de que tudo o que vê à sua volta lhe pertence, ao vislumbrar o professor de feição macambúzia, sentado à varanda, a amante do major-general decidiu que ele também lhe pertenceria, assim como os ornamentos que enfeitavam a sua sala melancólica. Fechado em seu mundo particular, o professor não nota a presença da mulher, que quanto mais se sente rejeitada, mais deseja possui-lo:

Não fosse o homem sentado na varanda em frente, [a amante do major-general] já se teria retirado para a macieza dos seus sofás de veludo e aí esperaria o amante que não tarda a chegar. Mas algo mais forte do que ela a retém de pé, travando esta luta surda e inglória que se arrasta desde o primeiro domingo em que depois do solitário almoço, ela se vestiu, maquilhou, perfumou e veio para a varanda. Nesse primeiro domingo, já lá estava o homem, sentado na cadeira de napa encardida, absorto no Xirico e na cerveja que, ao longo da tarde, iria bebendo. [...] O homem, porém, ignorou a presença daquela mulher que, da sua varanda o observava, toda oferecida e convicta do seu poder de sedução. E continua a ignorá-la, todos os domingos, ao longo de dois anos. (Momplé, 1997, p.12-13)

No trecho em destaque, consideramos relevante nos atentarmos para a focalização dos detalhes que configuram o espaço físico descrito pela voz narrativa. Observemos que a amante do major-general, enfeitada com as melhores maquiagens e com o seu vestido de seda, aconchegava-se na "macieza dos seus sofás de veludo". Em contraste com a imagem exuberante da mulher, a voz narrativa nos descreve o professor como um homem de "rosto grave e melancólico", de "mãos ossudas e nervosas", sentado em sua "cadeira de napa encardida". Temos, assim, a representação de dois cenários distintos: de um lado, o ambiente rico e luxuoso em que habitava a amante do major-general; do outro, o mundo cheio de privações em que viviam o professor e os seus familiares. Ao analisarmos esses dois espaços, podemos observar marcas da violência sistêmica. Uma violência instaurada, estruturada e institucionalizada. Em estudo sobre "Stress", a professora Zuleide Duarte assim se posiciona a respeito do contraste social apresentado no conto: 
O contraste entre a ninfa da varanda e o torturado torcedor, espectador do Xirico, diversão de domingo, com um inseparável e único copo de cerveja, revela uma nova discriminação, oriunda não mais da ação direta do português colonizador, mas do produto de uma luta que teve seus princípios nacionalistas desvirtuados, reduzindo-se a um mero jogo de gerir os próprios interesses. Um retrato duro dos que ganharam com a guerra em contraponto com os que perderam e continuam, não importando de quem vem o ataque: do invasor ou do estômago faminto. (Duarte, 2012, p.6)

O responsável por manter o luxo e ostentação que cercam a mulher é o major-general, um ex-guerrilheiro da FRELIMO ${ }^{4}$. Embevecido pelo poder, o major "se entrega aos seus ínfimos instintos, rumo a um hedonismo patológico, e aproveita a sua posição de alto oficial do exército para 'escravizar' a mulher, exigindo gratidão e respeito" (Rex, 2007, p. 445). Desfrutando das benesses dos postos cada vez mais elevados que assume, à medida que a guerra civil vai se prolongando, o homem que lutara pela libertação do país vai sendo dominado pela "ânsia desenfreada de usufruir tudo o que na vida lhe dá prazer" (Momplé, 1997, p.14). Mesmo que esses prazeres sejam frutos da miséria em que vive grande parte da população, sobretudo, o grupo atingido diretamente pela guerra.

O modo como a voz narrativa descreve o major e o professor é relevante para entendermos o processo de construção dessas duas personagens. O ex-guerrilheiro da FRELIMO é descrito pelo narrador como uma figura em processo de deformação. O homem, antes idealista, se transforma e a sua imagem se deforma. Cego pelo poder, o major vai ficando cada vez mais desfigurado, à medida que vai acumulando mais riquezas e abandonando os seus ideais. O excerto do conto abaixo nos mostra esse processo de deformação no/do corpo do major:

O major general é um quarentão pequeno e nervoso que conserva ainda resquícios do aprumo dos seus tempos de guerrilheiro da FRELIMO. [...] Actualmente, não só o aprumo, mas os próprios ideais que o nortearam durante a luta de libertação, e pelos quais estaria disposto a sacrificar a própria vida, foram se diluindo. [...] Não admira, pois, que o ventre, atufalhado de boa comida e farta bebida, se apresente agora volumoso e flácido, projectando-se o corpo como uma caricata gravidez. E que o rosto, outrora de contornos quase ascéticos, esteja agora deformado pela camada de gordura que, ao longo dos últimos anos, se vem instalando sob a pele macerada. E que o próprio olhar tenha adquirido a baça frieza da maioria dos abastados deste mundo. (Momplé, 1997, p.14-15)

Já mencionamos anteriormente que a voz narrativa dos contos de Momplé não é imparcial. De tal modo, sem o menor temor de tomar partido e fazer julgamentos, o narrador demonstra o seu sentimento de repulsa em relação ao major. Todas as expressões que utiliza para descrever o ex- 
-guerrilheiro trazem uma carga pejorativa: "ventre volumoso e flácido", "caricata gravidez", "rosto deformado pela camada de gordura", "pele macerada", "olhar de baça frieza". As características físicas e psicológicas do major são ressaltadas com a intenção de representá-lo como uma figura decadente. Em oposição a essa representação caricata do major-general, a voz narrativa apresenta o professor, destacando muitas das suas qualidades, o que lhe confere uma áurea de dignidade. De acordo com o narrador:

[O professor] desperta sempre com a sensação de que já está atrasado, arranja-se a correr e a correr engole a chávena de chá quase amargo (o açúcar é caro) e o pedaço de pão seco. [...] E a corrida recomeça, manhã à noite, inglória corrida que mal dá para a família não morrer de fome, estranha recompensa para tamanho esforço e tantos anos de estudo. Ah! Ultimamente tem havido algumas surpresas. São os familiares fugidos da guerra, que encontram abrigo certo em casa do professor, porquanto este bebeu no leite materno o espírito de hospitalidade que o leva a acolhê-los e a repartir com eles o pouco que possui. (Momplé, 1997, p. 16)

Observemos que a voz narrativa não economiza qualificativos para descrever a figura grandiosa do professor. Trabalhador, honesto, incorruptível e generoso, o homem é apresentado como um exemplo de dignidade, num contexto em que os homens que lutaram pela independência do país, considerados heróis pela população, vão sendo corrompidos pelo dinheiro e pelo poder, como é o caso do major-general.

Feitas estas observações a respeito de duas personagens masculinas tão diferentes, e que consideramos relevantes para compreendermos as estratégias narrativas utilizadas por Lília Momplé, voltemos à questão que é o foco principal de nossa análise: o ódio da amante do major-general pelo seu vizinho. Esse ódio moverá as ações da protagonista, sendo o professor a sua principal vítima. Certa do seu poder de sedução, a amante do major-general não aceita passar despercebida, tentando buscar no homem que lhe é indiferente "a confirmação da sua feminilidade e beleza" (Momplé, 1997, p.13). A ação, mesmo que inconsciente do professor ignorar a vizinha que tanto o deseja, vai fortalecendo o ódio desta. De tal modo,

Radiosa no seu vestido verde mar, ao vê-lo todo entregue à bebida e ao Xirico, a amante do major-general continua a fixá-lo com um olhar branco de rancor. O mesmo olhar que um dia, num futuro não muito distante, sentado no banco dos réus, ele irá captar e o levará a interrogar-se, cheio de perplexidade, "porque me odeia tanto esta mulher que mal conheço?” Com efeito, terá dela apenas uma ideia vaga e imprecisa, de alguém que, casualmente, se avista de relance. ( Momplé, 1997, p.13)

A estratégia narrativa, assumida por Lília Momplé, de trazer para o tempo presente pistas dos acontecimentos que marcarão o futuro das personagens, chama-se flashforward. Além do flashforward, a autora tam- 
bém recorre muitas vezes ao uso do flashback. Neste caso, fatos do passado são trazidos à tona para dar sentido a acontecimentos ocorridos no presente das personagens. Na citação destacada, vimos que a amante do major-general e o professor vão estar frente a frente, no momento em o homem estará sentado no banco dos réus, perplexo com o ódio que desperta na mulher que mal conhece. Logo, a voz narrativa nos revela o motivo deste encontro. O fato é que, num momento de desespero, o professor acaba assassinando a sua esposa. Ninguém presencia o crime. A amante do major-general, no entanto, ao saber do assassinato, faz questão de se apresentar como testemunha:

Nesse dia, a amante do major-general será a única testemunha de acusação. Nem mesmo os familiares da esposa do réu se prestarão a depor contra ele, porque, apesar de campónios analfabetos, carregam em si uma sabedoria antiga que lhes permite distinguir um criminoso de um homem acuado pelo desespero. A amante do major-general, porém, logo que tiver conhecimento da tragédia, ousando mesmo contrariar o amante, apresentar-se-á como testemunha de acusação, aproveitando-se da privilegiada situação de vizinha do réu. E, nessa hora de vingança, incriminará o professor com afirmações temerárias e falsas. (Momplé, 1997, p.13-14)

Mais do que a vingança, a disposição da personagem para ser testemunha de um crime que nem sequer presenciou pode ser vista como uma maneira desta conseguir movimentar sua rotina entediante. De tal modo, no momento em que presta o seu testemunho contra o professor, quando o juiz a proíbe de emitir opiniões pessoais sobre o réu, e, logo após, dá a sentença do crime, assim é descrita a reação da mulher:

Ela abster-se-á de emitir opiniões pessoais, mas continuará a fixar o réu com os olhos brancos de rancor. Rancor que dará lugar a um brilho de triunfo quando, apesar de todas as atenuantes, for lida a pesada sentença de quinze anos de prisão. (Momplé, 1997, p.13-14)

Como já mencionamos, a perspectiva na qual a história é narrada aponta, todo o tempo, para a construção de algumas personagens que são colocadas como vítimas e outras como culpadas pela violência que sofrem e/ou praticam. É perceptível a estratégia narrativa de focalizar, sobretudo, a violência assumida pela amante do major-general. A mulher, beneficiária direta do homem que lucra com a desgraça do povo, provoca antipatia no narrador, que não se exime de apontar todas as suas características negativas. A personagem feminina é descrita como fria, oportunista, rancorosa, vingativa, de natureza perversa e que se regozija com a miséria alheia. Vê-se que na figura da mulher exibem-se traços da burguesia egoísta e insensível de Moçambique, que, mergulhada em sua ambição e na ânsia desenfreada pelo poder, não consegue enxergar - ou prefere não ver - a situação lastimável em que vive grande parte da população que sofre com os efeitos maléficos da guerra. 
Contudo, por mais que a voz narrativa descreva a personagem feminina de maneira tão negativa, nos arriscamos a dizer que ela também é uma vítima. Saindo de um contexto de privações, vindo de uma família muito pobre, a protagonista do conto encontrou no major-general a possibilidade de ter uma vida melhor. Temendo ser descartada pelo amante, a mulher faz de tudo para agradá-lo: vai recebê-lo à porta de casa, como ele gosta, serve-lhe a bebida, como ele exige, e contenta-se em receber a visita do homem apenas uma vez por semana. Aliás, considera "muito lisonjeiro que este lhe reserve as tardes e as noites de domingo, pois, só em ocasiões excepcionais, ele as passa com a esposa e os filhos" (Momplé, 1997, p. 15).

Acreditamos que a personagem se mantém presa à relação com o major-general porque se beneficia dela, mas, mesmo que quisesse sair desse relacionamento, seria bem difícil obter êxito. O major, sendo um homem poderoso, dificilmente aceitaria que a mulher o deixasse, cabendo só a ele tomar essa decisão. É possível dizer que o major-general e a sua amante são "separados em duas categorias: uma dominante, outra dominada" (Saffioti; Almeida, 1995, p.23). A personagem feminina é o elo mais fraco da relação e, não tendo poder para violentar o poderoso homem, acaba por despejar a sua fúria no professor. Na opinião de John Rex, ao escolher o vizinho como alvo de seu ódio, a mulher procura descarregar a sua ira "salvando e preservando o seu mundo ir(real), e certamente a sua saúde emocional" (Rex, 2007, p. 446). Presa a uma realidade que a torna infeliz, a amante do major-general transforma-se em pessoa egoísta que só valoriza aquilo que o dinheiro pode comprar. Se pudesse, compraria o professor para incluí-lo na coleção de objetos que enfeitam a sua casa. Arriscamo-nos a afirmar que encher a mansão de móveis caros e luxuosos é uma maneira da mulher tentar preencher o vazio de sua existência.

É interessante observarmos as estratégias narrativas utilizadas por Lília Momplé para construir as personagens principais que praticam algum tipo de violência. A amante do major-general, como vimos, é representada como alguém que age de maneira temerária. Ela é vítima de violência, mas reproduz essa prática contra quem considera mais fraco, apenas para se vingar. Todas as qualificações que se referem à mulher a colocam num espaço de vilania. Por outro lado, mesmo quando assassina a esposa, o professor não perde a sua áurea heroica. Depois de cometer o crime, ele vai se entregar à polícia. Neste momento, ocorre uma virada na construção formal do texto, que reforça a tentativa do narrador tentar justificar o crime praticado pelo personagem com o qual muito se identifica. Nessa cena, diferente do que acontece no decorrer do conto, o professor assume a enunciação e se pronuncia num discurso direto livre:

- Venho entregar-me. Matei a minha mulher.

-Matou a sua mulher? - pergunta o polícia, atónito, pois não consegue relacionar aquele homem de aspecto tão pacífico com um crime de morte. 
-Sim, matei - murmura de novo, o professor.

-E por quê? Qual foi o móbil do crime?- Insiste o polícia, num tom mais profissional, mas ainda incrédulo.

-Não sei. Acabo de a matar.

- Não sabe? Então acaba de matar a mulher e não...

- Não sei... talvez porque eu próprio já não consiga viver responde o professor, tirando do bolso um velho lenço, com o qual tenta ocultar as lágrimas que, teimosamente, lhe brotam dos olhos. (Momplé,1997, p.19)

Neste diálogo final, onde prevalece a enunciação do professor, as poucas intervenções feitas pela voz narrativa são para reforçar o caráter dócil e inofensivo do pobre homem. O professor é encenado "antes como vítima de uma série de forças desses 'tempos modernos', mas que ele não consegue gerir. E acaba vitimando, de maneira fatal, a normalmente compreensiva mulher que também é sujeita a semelhante dificuldade" (Rex, 2007, p. 447). O modo como é narrada a confissão do homicida pode ser compreendido como uma estratégia utilizada por Momplé para criar uma maior aproximação entre nós, leitoras e leitores, e o personagem. A confissão do crime coloca, mais uma vez, o professor no espaço de celebração, coloca-o no lugar de herói que não foge às suas responsabilidades. Afinal, ele comete o erro, mas admite-o.

Se formos pensar nos personagens como alegorias, podemos dizer que o major-general representaria os indivíduos responsáveis pela perpetuação da guerra, recebendo benefícios diretos. A sua amante seria uma alegoria do grupo que se beneficia indiretamente do conflito. De certa forma, nos móveis luxuosos que enfeitam a mansão da mulher respinga o sangue das moçambicanas e dos moçambicanos mortos em consequência dos conflitos. Por não se deixar corromper e manter firmes os seus ideais, num contexto em que as pessoas vão sendo pervertidas pelo poder, o professor, em sua luta incansável pela sobrevivência, pode ser lido, no conto, como uma alegoria do povo moçambicano sofrido. Um defensor de valores e tradições do país que, aos poucos, vão sendo destruídos pela guerra que se estende infinitamente.

Podemos considerar, então, que a violência internalizada pela amante do major-general se manifesta na vida de todas as personagens do conto, em maior ou menor escala. A narrativa de Momplé é, portanto, marcada por uma áurea violenta. Ninguém consegue ficar imune a ela. A relação de violência que a personagem feminina estabelece com o major é reproduzida, por ela, contra o vizinho. Do mesmo modo, quando o professor assassina a sua mulher, ele pratica contra a esposa a violência do sistema que enfrenta cotidianamente. 
O conto "Stress", como grande parte das narrativas de Lília Momplé, não tem happy end. Ciente da realidade brutal que invade o contexto enfocado pelo conto, a autora vai criando estratégias de ficcionalização da violência, deixando manifesta a sua crítica àqueles que, como o major-general e sua amante, se beneficiam das mazelas provocadas pela guerra e pela corrupção dos ideais defendidos pelas lutas de libertação.

\section{REFERÊNCIAS BIBLIOGRÁFICAS}

ALÓS, Anselmo Peres. A ficcionalização da história moçambicana nos contos de Lília Momplé. Rev. Estud. Fem. Florianópolis, v. 19, n. 3, p. 1005-1007, Dez. 2011.

Disponível em: http://www.scielo.br/scielo.php?script=sci_ arttext\&pid=S0104-026X2011000300018. Acesso em: 25 ago. 2017.

ALÓS, Anselmo Peres. Uma leitura a contrapelo do colonialismo em terras moçambicanas. Rev. Estud. Fem. Florianópolis, v. 21, n. 1, p. 398402, Abr. 2013. Disponível em: http://www.scielo.br/scielo.php?script=sci_ arttext\&pid=S0104-026X2013000100021\&lng=pt\&nrm=iso. Acesso em: 25 ago. 2017.

DUARTE, Zuleide. Lilia Momplé: estórias de uma história contada com lágrimas. Rev. Literatas. Maputo, v.43, n.2, p. 05-07. Ago. 2012. Disponível em: http://macua.blogs.com/files/especial-lilia-momple.pdf. Acesso em: 26 ago. 2017.

MOMPLÉ, Lília. Os olhos da cobra verde. Maputo: Associação dos escritores moçambicanos, 1997.

MOMPLÉ, Lília. Entrevista: "se não escrever mais nada não me importo”. Rev. Literatas. Maputo, v.43, n.2, p. 09-13. Ago. 2012. Disponível em: http://macua.blogs.com/files/especial-lilia-momple.pdf. Acesso em: 26 ago. 2017.

REX, John. A oralidade escrita, ou a voz continuadora da matriarca africana em Lília Momplé e Ama Atta Aidoo. In: MATA, Inocência; PADILHA, Laura Cavalcante. A mulher em África: vozes de uma margem sempre presente. Lisboa: Edições Colibri/Centro de Tempo e Espaços Africanos, 2007.

SAFFIOTI, Heleieth; ALMEIDA, Suely Souza de. Violência de Gênero: poder e impotência. Rio de Janeiro: Livraria e Editora Revinter, 1995.

VISENTINI, Paulo Fagundes. A revolução moçambicana. In: As revoluções africanas: Angola, Moçambique e Etiópia. São Paulo: Editora da Unesp, 2012. 


\section{NOTAS}

1 Doutora em Letras - Literaturas de Língua Portuguesa - pela Pontifícia Universidade Católica de Minas Gerais - PUC Minas (2018). Pesquisadora visitante na Faculdade de Letras da Universidade de Lisboa (2017), pelo programa de doutorado-sanduíche da CAPES. Mestra em Estudos Literários pela Universidade Federal de Viçosa (UFV). Possui graduação em Letras Português/Espanhol pela Universidade Estadual de Santa (UESC). É pesquisadora associada ao Latin American Studies Association, da University of Pittsburgh. Integrante do Grupo de Estudo 'Estéticas Diaspóricas' - GEED, da PUC Minas, e do Núcleo de Estudos Afro-brasileiros (NEAB Viçosa). Tem experiência na área de Letras, atuando principalmente nos seguintes temas: Literatura Contemporânea; Literaturas Africanas de Língua Portuguesa; Literatura Afro-brasileira; Produções Literárias de Mulheres; Gênero; Violência e Literatura; Relações Étnico-raciais.

2 Em Angola e Moçambique a palavra xirico se refere a um aparelho portátil receptor de rádio.

3 A guerra civil moçambicana, iniciada pouco tempo após a guerra de independência, levaria o país à beira de do colapso pela destruição que ela iria provocar. Ela seria fruto de uma mescla de fatores internos e externos, sendo incentivadas principalmente pela reação às políticas do governo e pela situação que se configurava no sul da África ao final dos anos 1970. Para entender como a situação moçambicana chegou a tal ponto é preciso analisar as ações do governo desde que assumiu o poder, assim como as relações estabelecidas com outros países, em especial a Rodésia e a África do Sul [...]. Além da complexa situação interna do país, os acontecimentos nos países vizinhos viriam a influenciar a guerra civil moçambicana, principalmente pela postura adotada pela Frelimo em relação à política interna dos dois regimes racistas. [...] Desde o primeiro momento, o presidente Samora Machel havia declarado seu apoio ao estabelecimento de governos de maioria negra nesses países, então governados por uma minoria branca. Isso levou a Rodésia e a África do Sul a apoiarem o grupo oposicionista Renamo, que enfrentaria a Frelimo numa sangrenta e brutal guerra civil. (Visentini, 2012, p. 98-99).

4 A FRELIMO foi fundada no dia 25 de junho de 1962, como resultado da unificação de três movimentos nacionalistas: Udenamo, Unami e Unam. Em seu primeiro congresso, a Frelimo definiu uma plataforma capaz de unir a libertação nacional e determinou a estratégia e a tática para atingir esses objetivos. [...] O movimento de libertação nacional em Moçambique elaborou um discurso e uma estratégia contra o colonialismo português dentro de um modelo bem particular de luta: incorporaram questões específicas da identidade africana, aliado a um discurso enquadrado aos paradigmas marxistas. (Visentini, 2012, p. 91). 